\title{
Large-scale movements in the oceanic environment identify important foraging areas for loggerheads in central Mediterranean Sea
}

Paolo Luschi', Resi Mencacci' ${ }^{1}$, Giulia Cerritelli', Luana Papetti², Sandra Hochscheid ${ }^{3}$

Affiliations:

1. Dept. of Biology, University of Pisa, via A. Volta 6, I-56126 Pisa, Italy

2. TartAmare -Centro di educazione ambientale e di didattica sul mare, Centro per la conservazione delle tartarughe marine, via San Sebastiano 84, I-58100 Grosseto, Italy

3. Stazione Zoologica Anton Dohrn, Villa Comunale, I- 80121 Napoli, Italy

Corresponding author:

Prof. Paolo Luschi, Tel: + 39 0502211376, email: paolo.luschi@unipi.it; ORCID: 00000001-7081-3507

Acknowledgments

The authors are grateful to Mariapia Ciampa, Gianluca Treglia, Fulvio Maffucci and the staff of Punta Campanella Marine Protected Area, TartAmare and A.D. Club Subacqueo Grossetano (Grosseto) for their help in the recovery and releases of tracked turtles. Funds were obtained from SZN, University of Pisa (Progetti di Ricerca di Ateneo, grant \#PRA_2016_1) and Regione Toscana (Bando Go-Green Mare 2014). One satellite tag was purchased from a grant to G. C. Hays from the Natural Environment Research Council of the U.K. (NERC, grant NER/A/S/2003/00302)

Conflict of Interest: The authors declare that they have no conflict of interest.

Ethical approval: All procedures performed in studies involving animals were in accordance with the ethical standards of the institution or practice at which the studies were conducted. Transmitter deployments were authorised by the Italian Ministry of Environment (Prot. nos. 002451/PNM, DPN-2010-0000872, 0042848/PNM 09 and DP2009-0023740). 


\begin{abstract}
Loggerhead sea turtles (Caretta caretta) are known to display a wide range of movement patterns during the different stages of their life cycle, but empirical information to document this extensive behavioural plasticity is still limited. This is especially true for large, adultsized individuals, that are thought to mainly forage in neritic areas. In the present paper, eight adult-sized loggerhead turtles were tracked using satellite telemetry to identify the location of their foraging grounds in the seas along the western coast of the Italian peninsula. Tracked turtles mostly stayed in the region between the Italian peninsula and the islands of Sicily and Sardinia, that was reached following quick, directed movements by the turtles from a release site to the north. In this area, two turtles took up residence in spatially-limited neritic sites along the coast, while the remaining six alternated circumscribed coastal stays with long-distance, circuitous movements in the oceanic environment. An utilization distribution analysis clearly identified an area, mostly comprising oceanic waters, that was continuously used by turtles in different seasons and years. The present results contribute to the still-limited knowledge of the spatial ecology of loggerheads frequenting the Western Mediterranean Sea and highlight the presence of a potentially important oceanic region in the Southern Tyrrhenian Sea where adult-sized turtles forage for extended periods. These findings increase our knowledge of complex life history traits of loggerhead turtles and provide important information to be considered for evidence-based conservation measures.
\end{abstract}

Keywords: adult-sized loggerheads; oceanic foraging; central Mediterranean Sea

\title{
Introduction
}

Satellite telemetry has provided a wealth of information on the movements of marine turtles which is radically changing our view of turtle movement ecology and spatial behaviour. This is especially true for loggerhead turtles (Caretta caretta), whose original life history model (Musick and Limpus 1997; Bolten 2003), largely accepted until a few years ago, is being questioned (e.g. McClellan and Read 2007; Casale et al. 2008). According to this model, after an initial phase of pelagic living in the oceanic environment, late juvenile loggerheads recruit to neritic areas where they remain until adulthood, while adults are thought to shuttle between residential neritic foraging grounds and the breeding sites. This view has been challenged by satellite telemetry findings that have shown a large amount of behavioural plasticity in both juvenile and adult loggerheads. In particular, large juveniles have been found not to always reside in neritic zones, but were rather often shown to display prolonged movements also over oceanic waters (e.g. McClellan \& Read 2007; Arendt et al. 2012a; Varo Cruz et al. 2016). Adults, too, have been sometimes observed foraging in oceanic zones while displaying wandering movements, either when tracked soon after migrating away from breeding/nesting areas (Hatase et al. 2002; Hawkes et al. 2006; Schofield et al. 2010; Pikesley et al. 2015; Mingozzi et al. 2016) or in periods outside the breeding season (Bentivegna 2002; Kobayashi et al. 2011; Casale et al. 2013; Luschi et al. 2013).

Given this marked behavioural variability, it is mandatory to collect as much data as possible to document the main features of loggerhead movement patterns, especially for seldom-studied life stages such as juveniles (Godley et al. 2008). Indeed, it is particularly difficult to equip non-nesting turtles, including males and juveniles, with tracking instruments, since they do not come ashore at any time and cannot be easily accessed or 
captured (but see Van Dam et al. 2008; Arendt et al. 2012b; Schofield et al. 2013). The most commonly used way to study males and juveniles relies on accidentally or deliberately caught individuals, that are released soon after capture (e.g. Limpus et al. 1993; Howell et al. 2010; Barcelo et al. 2013; see also Ehrhart and Ogren 1999) or after a period spent in captivity for rehabilitation (e.g. Bentivegna 2002; Cardona et al. 2012; Dalleau et al. 2014). In this way, it has been possible to obtain an initial picture of the movements performed of loggerhead juveniles and adult males, but the available information remains scant and fragmentary, especially for large juveniles in the late stage of their developmental period.

In this study, we present satellite tracking data obtained for eight adult-sized loggerhead turtles that were incidentally captured while foraging in the Tyrrhenian Sea, western Mediterranean. Loggerheads are the most abundant turtle species in the Mediterranean, and are widely distributed throughout the whole basin, although nesting sites are mainly concentrated in its eastern part (Casale and Margaritoulis 2010). Studies involving mark and recapture, satellite tracking and distance sampling techniques have shown that Mediterranean loggerheads disperse widely, both as juveniles and as adults (Luschi and Casale 2014), frequenting virtually all the available areas of the basin, including the most northern ones (e.g. Casale et al. 2012a; Hochscheid et al. 2010; Lauriano et al. 2011). Data on the movements made in the Western Mediterranean (West of Sicily) are however not abundant, and are mainly restricted to turtles tracked in the westernmost area between Spain and Algeria (Cardona et al. 2005, 2009, 2012; Revelles et al. 2007a; Eckert et al. 2008 ), with only a few turtles ( $n=15$ in total in 5 studies) having been tracked in the Ligurian and Tyrrhenian seas along the western coast of the Italian peninsula (Bentivegna 2002; Hochscheid et al. 2007, 2010; Mencacci et al. 2011; Luschi et al. 2013). Using this approach, we intended to investigate whether large turtles, which are presumably in their neritic developmental stage, still make extensive use of oceanic foraging areas and to identify the location and extension of the most frequented sites in the region. Such information is important to decipher complex life history traits of sea turtles and design adhoc management plans for this threatened species.

\section{Materials and methods}

Tracked turtles were captured in various areas of the Tyrrhenian Sea, having been incidentally caught by bottom trawlers, found floating (turtle T6) or entangled in nets (turtle T8). Before release, they had been kept in captivity for a variable period (range 30-463 days; table 1) to be rehabilitated by Rescue Centres operating in the areas.

Curved carapace length (CCL) of all turtles was above $60 \mathrm{~cm}$, and so they can be considered in the subadult-adult stage of their life cycle, given that the minimum CCL of females nesting in Mediterranean rookeries is around 65-70 cm (Margaritoulis et al. 2003) and that males attains sexual maturity at a size of at least $75 \mathrm{~cm} \mathrm{CCL}$ (Casale et al. 2005). Based on their size, external morphology and on the presence/absence of male sexual characteristics (Casale et al. 2005), turtles T2, T4, T5, T6 and T7 were considered adults and ultrasound scanning indeed revealed that turtle T2 had eggs developing in her ovary at the time of release. The other turtles, with CCLs ranging between 63 and $68 \mathrm{~cm}$ at the time of release, were likely approaching sexual maturity.

Turtles were released from locations close to the capture sites, after having been equipped with various models of Argos-linked satellite transmitters (table 1), that were attached 
using standard attachment procedures with epoxy resins. The units were programmed to transmit with different duty cycles (table 1).

The Argos system assigns a level of decreasing accuracy to locations obtained: classes 3 , 2 and 1 are the most accurate (generally within $1 \mathrm{~km}$ of the true position; Witt et al. 2010), while low-quality classes $0, A$ and $B$ have no accuracy estimation. The data were managed by STAT program (www.seaturtle.org; Coyne and Godley 2005) and the routes were reconstructed by filtering out low-quality locations that were on land or which inferred movement speeds above a pre-determined individual speed threshold. Speed thresholds were determined for each turtle by assessing the maximum speed between locations of classes 3, 2, and 1 that were obtained at least $1 \mathrm{~h}$ apart and then adding a $20 \%$ buffer to this value (see also Lambardi et al. 2008; Dujon et al. 2017). A minimum individual speed threshold of $4 \mathrm{~km} / \mathrm{h}$ was applied. The number of locations obtained varied between 1.4 and 21.7 per day, with an average of $27 \%$ of fixes of appropriate quality having been obtained less than $1 \mathrm{~h}$ apart. Data filtering eliminated the $32 \%$ of locations on average (range $24-51 \%$ ).

To identify high-use areas in the Tyrrhenian Sea, the utilization distribution (UD) of each turtle was estimated (Worton 1989) by selecting only one fix per day and choosing the one with highest accuracy and the one closest to midday if more than one fix had the same accuracy (Zbinden et al. 2008). Individual turtles' core areas were identified by applying the Area Independent Method developed by Seaman and Powell (1990). The method divides the home range in areas of high- and low- use using an objective criterion, and is based on a graphical representation of the home range area in relation to its use (Kernel UD volume contour). In this way it is possible to identify the dividing point between highand low-use areas, as the point where the plot is maximally distant from a straight line of slope \pm 1 , that represents a distribution of random use. We performed the analysis using steps of $5 \%$ and for all our turtles the point of maximum distance was reached at a value close to $30 \%$ volume contour. As a result, we defined the core areas as $30 \%$ Kernel UD. The core area polygons were calculated with a fixed kernel technique with reference smoothing parameter (Worton 1989). Calculations were made with the adehabitatHR package (Calenge 2006) in R 3.3.3 (R core team 2017).

\section{$\underline{\text { Results }}$}

Six of the eight turtles were tracked for more than four months after release, up to a maximum of 314 days (table 1; Fig. S1). The three turtles from the Northern Tyrrhenian Sea moved southward soon after release, with turtle T3 taking a route closely following the coastline and the other two turtles moving in the open sea (Fig. 1). In this way they quickly reached an area south of $41^{\circ} \mathrm{N}$, where the other turtles released in South Tyrrhenian Sea also remained for several months (Fig. 2). Turtles T3 and T1 took residence in limited coastal sites around the Gulf of Naples where they were tracked for 30 and 111 days (Fig. $1)$, while performing short-range movements in restricted $(<50 \mathrm{~km})$ sites, moving at low speed (mean \pm SEM: $0.88 \pm 0.20 \mathrm{kmh}^{-1}$ for T1, $0.76 \pm 0.02 \mathrm{kmh}^{-1}$ for T3). Turtle T3 was then found dead after 44 days of tracking stranded along the coast north of Gulf of Naples; a successive necropsy did not reveal any evident cause of death.

The other six tracked turtles, conversely, alternated circumscribed movements in sites along the southwestern Italian peninsula with long-distance circuitous movements in oceanic waters in the area comprised between the peninsula, Sicily and Sardinia islands 
(Fig. 1, 2). For these turtles, the percentage of locations occurring in oceanic ( $>200 \mathrm{~m}$ deep) waters ranged between $75 \%$ and $96 \%$. Turtles frequented this oceanic area both during winter (e.g. turtles T2, T7, T8) and summer (e.g. turtles T2, T4, T5) months (Fig. $\mathrm{S} 1)$, and they mostly performed movements at low speed $\left(<2 \mathrm{kmh}^{-1}\right)$.

Only two turtles left this general area while they were being tracked: turtle T8 to move northward in April 2007, and turtle T6 first to circumnavigate Sicily in Feb. 2010, and then to enter the south Ionian Sea in July 2010. During these legs, too, turtles moved at speeds below $2 \mathrm{kmh}^{-1}$.

The UD analysis identified an area in south-eastern Tyrrhenian Sea where all tracked turtles remained for long time (Fig. 3), despite having been tracked in different seasons and years. Each tracked turtle was localised inside this area for at least 3 weeks (range 334 weeks, corresponding to $60-100 \%$ of total tracking time; Fig. S1). Core areas of individual turtles were generally in this region (Fig. 4), although differences among turtles were also evident, with some individuals mostly frequenting coastal waters (T3, T5, T6) and others remaining in oceanic areas (Fig. 4). As a result, the overlap between different core areas was limited (Fig. S2): the mean proportion of overlap among individual core areas was $0.13 \pm 0.17 \mathrm{SD}$, with all overlaps smaller than $35 \%$, except for the core areas of turtles T1 vs. T3 and T4 vs T5, which overlapped by about $80 \%$. The size of individual core areas ranged between 2725 and $20682 \mathrm{~km}^{2}$. Core area sizes were smaller in winter than in summer, both when considering the mean size for the whole sample (means \pm SEM $9603 \pm 911 \mathrm{~km}^{2}$ vs $13125 \pm 2150 \mathrm{~km}^{2}, \mathrm{n}=4$ and 6 , respectively) and for just the two turtles that had been tracked both in summer and winter months (turtle T2: winter, 8965 km²; summer 17418 km²; turtle T6: winter, 4979 km²; summer 13736 km²).

\section{Discussion}

The results of the present study further highlight the high behavioural plasticity of loggerhead turtles and provide a substantial contribution to increase our poor knowledge of the distribution and spatial ecology of loggerheads frequenting the Western Mediterranean Sea, and in particular its eastern portion. They also highlight the potential importance of the offshore area between the Italian peninsula, Sardinia and northern Sicily, where tracked turtles spent a large amount of their time in different months/seasons and in different years (Fig. 3, S1), even when they were released far from this location (Fig. 1). The seas adjacent to the west coast of Italy and around the two largest Mediterranean islands (Sardinia and Corsica) are known to host quite a large number of loggerheads, foraging in either coastal or pelagic areas (Casale and Margaritoulis 2010; Lauriano et al. 2011). These findings, although based on a limited sample size, help clarifying the locations of their preferred foraging/residential sites, providing the first evidence of the oceanic foraging areas used by loggerheads in the region. A recent survey covering a large part of the Tyrrhenian Sea has indeed reported a large number of loggerhead sightings in the offshore waters of its southern portion, that broadly correspond to those frequented by our tracked turtles (Fiori et al. 2016). Finally, loggerhead strandings are also not infrequent in the area, again especially along the southern coasts (Casale et al. 2010).

Information on the movements and at-sea behaviour of turtles in the seas west of Italy is limited to a few routes recorded in accidentally-caught and rehabilitated turtles (Bentivegna 2002; Hochscheid et al. 2010; Mencacci et al. 2011; Luschi et al. 2013). Turtles previously tracked in the area were somewhat smaller than those of our sample, and mostly 
displayed movements in the neritic areas, with prolonged residence in coastal sites being shown in all studies. Only a few turtles undertook long-distance movements in the oceanic environment (Bentivegna 2002), and most of these occurred outside the Tyrrhenian Sea (Bentivegna 2002; Hochscheid et al. 2010; Luschi et al. 2013). The tendency to leave the Tyrrhenian Sea was only noted in turtle T6 in our sample. Conversely, turtles tracked from other Mediterranean areas have rarely been found to enter the Tyrrhenian Sea. For instance, of the nearly 50 published routes for turtles released from the Spanish coast (Cardona et al. 2005, 2009, 2012, Revelles et al. 2007a, 2007b; Eckert et al. 2008), only one juvenile (CCL $53 \mathrm{~cm}$ ) was tracked as it reached the waters northwest of Sicily and then moved northward (Eckert et al. 2008).

On the whole, the results of the present study further confirm the large behavioural variability shown in the movements of loggerhead turtles, especially during the juvenile/non-breeding stages. According to the widely accepted scheme of the loggerhead life cycle (Musick and Limpus 1997; Bolten 2003), large juveniles like those tracked in this study that likely were approaching sexual maturity, should inhabit neritic, mostly coastal, waters while foraging on benthic prey. Conversely, our data clearly show that large loggerhead juveniles spend most of their time foraging in the oceanic environment, although they can also frequent coastal areas for limited periods. These findings are in line with previous studies that have revealed similar prolonged offshore residences in large juvenile loggerheads (CCL $>60 \mathrm{~cm}$ ) moving in several different areas, like the western Atlantic Ocean (McClellan and Read 2007), the central Pacific Ocean (Kobayashi et al. 2008) and the Western Mediterranean Sea (e.g. Eckert et al. 2008; Cardona et al. 2009; Zbinden et al. 2011; Schofield et al. 2013). In our study area, the presence of adult-sized individuals has been documented by analyses of bycatch data, which have shown that turtles of this size are captured more often by pelagic longlines than by bottom trawls (Casale 2011). Offshore residence, often in conjunction to extended movements over large areas, should therefore be regarded as a common feature of the spatial ecology of latejuvenile loggerheads. It is worth recalling here that these turtles had been released after a rehabilitation period in rescue centres, so their behaviour might not completely correspond to that of individuals in the wild. However, no indications of any abnormal behaviour were evident for the turtles in this study, either with respect to their overall movement patterns or other aspects such as their diving or surfacing pattern (data not shown). This is in general accordance with previous studies with rehabilitated individuals that have shown no major anomalies in post-release behaviour (e.g. Polovina et al. 2006; Rees et al. 2013; Robinson et al. 2017; but see also Cardona et al. 2012).

It is clear that when moving for such long periods in oceanic waters, loggerheads will have to shift from their usual feeding habit on benthic prey to some form of epipelagic feeding (e.g. Hatase et al. 2002; McClellan and Read 2007), which further highlights the large behavioural plasticity of loggerheads. Epipelagic feeding will likely also affect the range of movements performed by the turtles, as it may be expected that feeding on patchy and highly dynamic food resources will require high mobility. Indeed, Mediterranean loggerheads have been shown to use multiple foraging areas (Schofield et al. 2010; 2013). Our results are in accordance with this view, showing that the most frequented areas of tracked turtles were indeed very large, typically spanning more than $13000 \mathrm{~km}^{2}$ (table 1). It is worth recalling that the volume contours used for these core area estimations (30\%) were objectively determined through the Area Independent Method, and so they are more precise in representing the turtles' highly used areas than the commonly used $50 \%$ contours. Much smaller core areas ( $<4000 \mathrm{~km}^{2}$, as determined by Kernel UD) have been described for loggerheads foraging in neritic (Marcovaldi et al. 2010 and references 
therein; Casale et al. 2013; Foley et al. 2013; Hart et al. 2015; Mingozzi et al. 2016), as well as in oceanic sites (Schofield et al. 2010, a single individual). Neritic juveniles, conversely, have been found to frequent areas larger than $10000 \mathrm{~km}^{2}$ (Casale et al. $2012 \mathrm{~b}$ ). The fact that our turtles stayed in smaller areas (still $>4000 \mathrm{~km}^{2}$ ) in winter than in summer is in accordance with previous findings in adult loggerheads (Broderick et al. 2007; Zbinden et al. 2008; Hawkes et al. 2011). Turtles T2 and T6 reduced their home range while remaining always in the same general area, a strategy previously shown in juveniles (Casale et al. 2012b).

The high variability of the oceanic habitats exploited by tracked turtles may also explain the limited overlap between high-use areas of different individuals: an area preferred by a turtle in one particular period/year might not be appealing to other turtles or at another time. Finally, it is worth noting that the Tyrrhenian Sea is characterised by quite a large number of seamounts, that represent foraging hotspots for marine fauna (Morato et al. 2010) and have indeed been found to attract top predators (Fiori et al. 2016). Interestingly, the core areas of tracked turtles did include several seamounts (Fig. S3), and on several occasions tracked turtles remained in close vicinity $(<20 \mathrm{~km})$ or passed over some of them (Fig. S4).

Recent conservation strategies for sea turtles highlight the need not only to ensure protection to coastal areas around well-known nesting/breeding sites (e.g. Schofield et al. 2009; Mazaris et al. 2014), but also to identify highly frequented offshore areas that are largely used by turtles outside the breeding season and where conservation efforts may be directed (Schofield et al. 2013). For instance, fishing activities and boat traffic constitute the major threats to sea turtles in the Mediterranean (Casale et al. 2010; Casale et al. 2011) and are likely to have a large impact on turtles frequenting the area identified in the current study, where fishing pressure and maritime traffic are high (Coll et al. 2012). Although it was not possible to definitively determine cause of death, turtle T3 was indeed found stranded after a period spent foraging in shallow waters very close to the coast (Fig. 1). The present findings, albeit obtained for only a few individuals, demonstrated the power of satellite telemetry as a tool for collecting direct observations of the areas actually frequented by marine turtles. We hope that future studies will confirm these findings: compiling the data yielded by the efforts of the different groups employing these techniques (e.g. Fossette et al. 2014) may then lead to identification of the main high-use areas in the Mediterranean basin, thus providing ground-truthed information to set up appropriate conservation plans for the Mediterranean Sea.

\section{References}

Arendt MD, Segars AL, Byrd JI, Boynton J, Whitaker JD, Parker L, Owens DW, Blanvillain G, Quattro JM , Roberts MA (2012a) Seasonal distribution patterns of juvenile loggerhead sea turtles (Caretta caretta) following capture from a shipping. Mar Biol 159:127-139

Arendt MD, Segars AL, Byrd JI, Boynton J, Schwenter JA, Whitaker JD, Parker L (2012b) Migration, distribution, and diving behavior of adult male loggerhead sea turtles (Caretta caretta) following dispersal from a major breeding aggregation in the Western North Atlantic. Mar Biol 159:113-125 
Barcelo C, Domingo A, Miller P, Ortega L, Giffoni B, Sales G, McNaughton L, Marcovaldi MA, Heppell S , Swimmer Y (2013) High use areas, seasonal movements and dive patterns of juvenile loggerhead sea turtles in the Southwestern Atlantic Ocean. Mar Ecol Prog Ser 479:235-250

Bentivegna F (2002) Intra-Mediterranean migrations of loggerhead sea turtles (Caretta caretta) monitored by satellite telemetry. Mar Biol 141:795-800

Bolten AB (2003) Active swimmers - passive drifters: the oceanic juvenile stage of loggerheads in the Atlantic System. In: Bolten AB, Witherington BE (eds) Loggerhead sea turtles. Smithsonian Institution, Washington, pp 63-78

Broderick AC, Coyne M, Fuller WJ, Glen F, Godley BJ (2007) Fidelity and over-wintering of sea turtles. Proc R Soc Lond B 274:1533-1538

Calenge C (2006) The package adehabitat for the R software: a tool for the analysis of space and habitat use by animals. Ecol Model 197:516-519

Cardona L, Revelles M, Carreras C, San Felix M, Gazo M, Aguilar A (2005) Western Mediterranean immature loggerhead turtles: habitat use in spring and summer assessed through satellite tracking and aerial surveys. Mar Biol 147:583-591

Cardona L, Revelles M, Parga M, Tomas J, Aguilar A, Alegre F, Raga A, Ferrer X (2009) Habitat use by loggerhead sea turtles Caretta caretta off the coast of eastern Spain results in a high vulnerability to neritic fishing gear. Mar Biol 156:2621-2630

Cardona L, Fernandez G, Revelles M, Aguilar A (2012) Readaptation to the wild of rehabilitated loggerhead sea turtles (Caretta caretta) assessed by satellite telemetry. Aquat Conserv 22:104-112

Casale P, Freggi D, Basso R, Argano R (2005) Size at male maturity, sexing methods and adult sex ratio in loggerhead turtles (Caretta caretta) from Italian waters investigated through tail measurements. Herpetol J 15:145-148

Casale P, Abbate G, Freggi D, Conte N, Oliverio M, Argano R (2008) Foraging ecology of loggerhead sea turtles Caretta caretta in the central Mediterranean Sea: evidence for a relaxed life history model. Mar Ecol Prog Ser 372:265-276

Casale P, Affronte M, Insacco G, Freggi D, Vallini C, D'Astore PP, Basso R, Paolillo G, Abbate G, Argano R (2010) Sea turtle strandings reveal high anthropogenic mortality in Italian waters. Aquat Conserv 20:611-620

Casale P, Margaritoulis D (2010) Sea turtles in the Mediterranean: Distribution, threats and conservation priorities. IUCN, Gland, Switzerland

Casale P, Mazaris AD, Freggi D (2011) Estimation of age at maturity of loggerhead sea turtles Caretta caretta in the Mediterranean using length-frequency data. Endang Species Res 13:123-129

Casale P, Affronte M, Scaravelli D, Lazar B, Vallini C, Luschi P (2012a) Foraging grounds, movement patterns and habitat connectivity of juvenile loggerhead turtles (Caretta caretta) 
tracked from the Adriatic Sea. Mar Biol 159:1527-1535

Casale P, Broderick AC, Freggi D, Mencacci R, Fuller WJ, Gadley BJ, Luschi P (2012b) Long-term residence of juvenile loggerhead turtles to foraging grounds: a potential conservation hotspot in the Mediterranean. Aquatic Conserv 22:144-154

Casale P, Freggi D, Cinà A, Rocco M (2013) Spatio-temporal distribution and migration of adult male loggerhead sea turtles (Caretta caretta) in the Mediterranean Sea: further evidence of the importance of neritic habitats off North Africa. Mar Biol 160:703-718

Coll M, Piroddi C, Alboui C, Ben Rais Lasram F, Cheung WWL, Christensen V, Karpouzi VS, Guilhaumon F, Mouillo D, Paleczny M, Palomares ML, Steenbeek J, Trujillo P, Watson R, Pauly D (2012) The Mediterranean Sea under siege: spatial overlap between marine biodiversity, cumulative threats and marine reserves. Global Ecol Biogeogr 21:465-480

Coyne MS, Godley BJ (2005) Satellite Tracking and Analysis Tool (STAT): an integrated system for archiving, analyzing and mapping animal tracking data. Mar Ecol Prog Ser 301:1-7

Dalleau M, Benhamou S, Sudre J, Ciccione S, Bourjea J (2014) The spatial ecology of juvenile loggerhead turtles (Caretta caretta) in the Indian Ocean sheds light on the "lost years" mystery. Mar Biol 161:1835-1849

Dujon AM, Schofield G, Lester RE, Esteban N, Hays GC (2017) Fastloc-GPS reveals the timing of departure and arrival during sea turtle migration and speed of travel patterns. Mar Biol DOI 10.1007/s00227-017-3216-8

Eckert SA, Moore JE, Dunn DC, Sagarminaga van Buiten R, Eckert KL, Halpin PN (2008) Modeling loggerhead turtle movement in the Mediterranean: importance of body size and oceanography. Ecol Appl 18:290-308

Ehrhart LM, Ogren LH (1999) Studies in foraging habitats: capturing and handling turtles. In: Eckert KL, Bjorndal KA, Abreu-Grobois FA, Donnelly M (eds) Research and management techniques for the conservation of sea turtles. IUCN/SSC Marine Turtle Specialist Group Publication 4, pp 1-4

Fiori C, Paolo C, Alessi J, Mandich A, Vassallo P (2016) Seamount attractiveness to top predators in the southern Tyrrhenian Sea (central Mediterranean). J Mar Biol Assoc UK 96:769-775

Foley AM, Schroeder BA, Hardy R, MacPherson SL, Nicholas M, Coyne MS (2013) Postnesting migratory behavior of loggerhead sea turtles Caretta caretta from three Florida rookeries. Endang Species Res 21:129-142

Fossette S, Witt MJ, Miller P, Nalovic MA, Albareda D, Almeida AP, Broderick AC, Chacon-Chaverri D, Coyne MS, Domingo A, Eckert S, Evans D, Fallabrino A, Ferraroli S, Formia A, Giffoni B, Hays GC, Hughes G, Kelle L, Leslie A, Lopez-Mendilaharsu M, Luschi P, Prosdocimi L, Rodriguez-Heredia S, Turny A, Vehage S, Godley BJ (2014) Pan-Atlantic analysis of the overlap of a highly migratory species, the leatherback turtle, with pelagic longline fisheries. Proc R Soc Lond B 281: 20133065 
Godley BJ, Blumenthal JM, Broderick AC, Coyne M, Godfrey MH, Hawkes LA, Witt MJ (2008) Satellite tracking of sea turtles: Where have we been and where do we go next? Endang Species Res 4:3-22

Hart KM, Sartain AR, Fujisaki I (2015) Bahamas connection: residence areas selected by breeding female loggerheads tagged in Dry Tortugas National Park, USA. Anim Biotelem 3: 3

Hatase H, Takai N, Matsuzawa Y, Sakamoto W, Omuta K, Goto K, Arai N, Fujiwara T (2002) Size-related differences in feeding habitat use of adult female loggerheads Caretta caretta around Japan determined by stable isotope analyses and satellite telemetry. Mar Ecol Prog Ser 233:273-281

Hawkes LA, Broderick AC, Coyne M, Godfrey MH, Lopez-Jurado L-F, Lopez-Suarez P, Merino SE, Varo-Cruz N, Godley BJ (2006) Phenotipically linked dichotomy in sea turtle foraging requires multiple conservation approaches. Curr Biol 16:990-995

Hawkes LA, Witt MJ, Broderick AC, Coker JW, Coyne M, Dodd CK, Frick MG, Godfrey MH, Griffin DB, Murphy SR, Murphy TM, Williams KL, Godley BJ (2011) Home on the range: spatial ecology of loggerhead turtles in Atlantic waters of the USA. Divers Distrib $17: 624-640$

Hochscheid S, Bentivegna F, Bradai MN, Hays GC (2007) Overwintering behaviour in sea turtles: dormancy is optional. Mar Ecol Prog Ser 340:287-298

Hochscheid S, Bentivegna F, Hamza A, Hays GC (2010) When surfacers do not dive: multiple significance of extended surface times in marine turtles. J Exp Biol 213:1328-1337

Howell E, Dutton DL, Polovina JJ, Bailey H, Parker D, Balazs GH (2010) Oceanographic influences on the dive behavior of juvenile loggerhead turtles (Caretta caretta) in the North Pacific Ocean. Mar Biol 157:1011-1026

Kobayashi DR, Polovina JJ, Parker D, Kamezaki N, Cheng IJ, Uchida I, Dutton PH, Balazs GH (2008) Pelagic habitat characterization of loggerhead sea turtles, Caretta caretta, in the North Pacific Ocean (1997-2006): Insight from satellite tag tracking and remotely sensed data. J Exp Mar Biol Ecol 356:96-114

Kobayashi DR, Cheng IJ, Parker DM, Polovina JJ, Kamezaki N, Balazs GH (2011) Loggerhead turtle (Caretta caretta) movement off the coast of Taiwan: characterization of a hotspot in the East China Sea and investigation of mesoscale eddies. ICES J Mar Sci 68:707-718

Lambardi P, Lutjeharms JRE, Mencacci R, Hays GC, Luschi P (2008) Influence of ocean currents on long-distance movement of leatherback sea turtles in the Southwest Indian Ocean. Mar Ecol Prog Ser 353:289-301

Lauriano G, Panigada S, Casale P, Pierantonio N, Donovan GP (2011) Aerial survey abundance estimates of the loggerhead sea turtle Caretta caretta in the Pelagos Sanctuary, northwestern Mediterranean Sea. Mar Ecol Prog Ser 437:291-302 
Limpus CJ (1993) The green turtle, Chelonia mydas, in Queensland: breeding males in the southern Great Barrier Reef. Wild Res 20:513-523

Luschi P, Mencacci R, Vallini C, Ligas A, Lambardi P, Benvenuti S (2013) Long-term tracking of adult loggerhead turtles (Caretta caretta) in the Mediterranean Sea. J Herpetol 47:227-231

Luschi P, Casale P (2014) Movement patterns of marine turtles in the Mediterranean Sea: a review. Ital J Zool 81:478-495

Marcovaldi MA, Lopez GG, Soares LS, Lima EHS, Thomé JCA, Almeida AP (2010) Satellite-tracking of female loggerhead turtles highlights fidelity behavior in northeastern Brazil. Endang Species Res 12:263-272

Margaritoulis D, Argano R, Baran I, Bentivegna F, Bradai MN, Caminas JA, Casale P, De Metrio G, Demetropoulos A, Gerosa G, Godley BJ, Haddoud DA, Houghton J, Laurent L, Lazar B (2003) Loggerhead turtles in Mediterranean Sea: present knowledge and conservation perspectives. In: Bolten AB, Witherington BE (eds) Loggerhead Sea Turtles. Smithsonian Books, Washington, pp175-198

Mazaris AD, Almpanidou V, Wallace B, Schofield G (2014) A global gap analysis of sea turtle protection coverage. Biol Conserv 173:17-23

McClellan CM, Read AJ (2007) Complexity and variation in loggerhead sea turtle life history. Biol Lett 3:592-594

Mencacci R, Ligas A, Meschini P, Luschi P (2011) Movements of three loggerhead sea turtles in Tuscany waters. Atti Soc tosc Sci nat, Mem, Serie B 118:117-120

Mingozzi T, Mencacci R, Cerritelli G, Giunchi D, Luschi P (2016) Living between widely separated areas: Long-term monitoring of Mediterranean loggerhead turtles sheds light on cryptic aspects of females spatial ecology. J Exp Mar Biol Ecol 485:8-17

Morato T, Hole SD, Allain V, Nicol S (2010) Seamounts are hotspots of pelagic biodiversity in the open ocean. Proc Natl Acad Sci USA 107:9707-9711

Musick JA, Limpus CJ (1997) Habitat utilization and migration in juvenile sea turtles. In: Lutz PL, Musick JA (eds) The biology of sea turtles. CRC Press, Boca Raton, pp 137-164

Pikesley SK, Broderick AC, Cejudo D, Coyne MS, Godfrey MH, Godley BJ, Lopez P, Lopez-Jurado L-F, Merino SE, Varo-Cruz N, Witt MJ, Hawkes LA (2015) Modelling the niche for a marine vertebrate: a case study incorporating behavioural plasticity, proximate threats and climate change. Ecography 38:803-812

Polovina JJ, Uchida I, Balazs G, Howell EA, Parker D, Dutton P (2006) The Kuroshio Extension Bifurcation Region: a pelagic hotspot for juvenile loggerhead sea turtles. DeepSea Res II 53:326-339

R Core Team (2017) R: A language and environment for statistical computing. R Foundation for Statistical Computing, Austria 
Rees AF, Hafez AA, Lloyd JR, Papathanasopoulou N, Godley BJ (2013) Green turtles, Chelonia mydas, in Kuwait: nesting and movements. Chelonian Conserv Biol 12:157-163

Revelles M, Isern-Fontanet J, Cardona L, San Felix M, Carreras C, Aguilar A (2007a) Mesoscale eddies, surface circulation and the scale of habitat selection by immature loggerhead sea turtles. J Exp Mar Biol Ecol 347:41-57

Revelles M, Cardona L, Aguilar A, San Felix M, Fernandez G (2007b) Habitat use by immature loggerhead sea turtles in the Algerian Basin (western Mediterranean): swimming behaviour, seasonality and dispersal pattern. Mar Biol 151:1501-1515

Robinson DP, Jabado RW, Rohner CA, Pierce SJ, Hyland KP, Baverstock WR (2017) Satellite tagging of rehabilitated green sea turtles Chelonia mydas from the United Arab Emirates, including the longest tracked journey for the species. PLoS ONE 12(9):e0184286

Rovere M, Bo M, Alessi J, Paoli C, Villani N, Vassallo P, Fiori C, Roccatagliata N (2015) Seamounts and seamount-like structures of the Tyrrhenian Sea. In: Würtz M, Rovere M (eds) Atlas of the Mediterranean Seamounts and Seamount-like Structures. IUCN, Gland, pp 111-186

Schofield G, Bishop CM, Katselidis KA, Dimopoulos P, Pantis JD, Hays GC (2009) Microhabitat selection by sea turtles in a dynamic thermal marine environment. J Anim Ecol 78:14-21

Schofield G, Hobson VJ, Fossette S, Lilley MKS, Katselidis KA, Hays GC (2010) Fidelity to foraging sites, consistency of migration routes and habitat modulation of home range by sea turtles. Divers Distrib 16:840-853

Schofield G, Dimadi A, Fossette S, Katselidis KA, Koutsoubas D, Lilley MKS, Luckman A, Pantis JD, Karagouni AD, Hays GC (2013) Satellite tracking large numbers of individuals to infer population level dispersal and core areas for the protection of an endangered species. Divers Distrib 19:834-844

Seaman DE, Powell RA (1990) Identifying patterns and intensity of home range use. Int Conf Bear Res and Manage 8:243-249

van Dam RP, Diez CE, Balazs GH, Colon Colon LA, McMillan WO, Schroeder BA (2008) Sex-specific migration patterns of hawksbill turtles breeding at Mona Island, Puerto Rico. Endang Species Res 4:85-94

Varo-Cruz N, Bermejo JA, Calabuig P, Cejudo D, Godley BJ, Lopez-Jurado L-F, Pikesley SK, Witt MJ, Hawkes LA (2016) New findings about the spatial and temporal use of the Eastern Atlantic Ocean by large juvenile loggerhead turtles. Divers Distrib 22:481-492

Witt MJ, Åkesson S, Broderick AC, Coyne MS, Ellick J, Formia A, Hays GC, Luschi P, Stroud S, Godley BJ (2010) Assessing accuracy and utility of satellite-tracking data using Argos-linked Fastloc-GPS. Anim Behav 80:571-581

Worton BJ (1989) Kernel methods for estimating the utilization distribution in home-range studies. Ecology 70:164-168 
Zbinden JA, Aebischer A, Margaritoulis D, Arlettaz R (2008) Important areas at sea for adult loggerhead sea turtles in the Mediterranean Sea: satellite tracking corroborates findings from potentially biased sources. Mar Biol 153:899-906

Zbinden JA, Bearhop S, Bradshaw CJ, Gill B, Margaritoulis D, Newton J, Godley BJ (2011) Migratory dichotomy and associated phenotypic variation in marine turtles revealed by satellite tracking and stable isotope analysis. Mar Ecol Prog Ser 421: 291-302 
Figure captions

Fig. 1 Reconstructed routes of the tracked turtles. a) Turtle T2, b) T1 (orange line) and T3 (dark blue line), c) Turtle T5 (blue line), T6 (pink line) and T8 (yellow line), d) T4 (coral line) and T7 (green line). Bathymetric information was taken from Natural Earth (naturalearthdata.com).

Fig. 2 Utilization distribution (UD) of the eight turtles tracked. Red stars indicate the release sites.

Fig. 3 Individually-specific core areas (30\% Kernel UD) for the tracked turtles. 

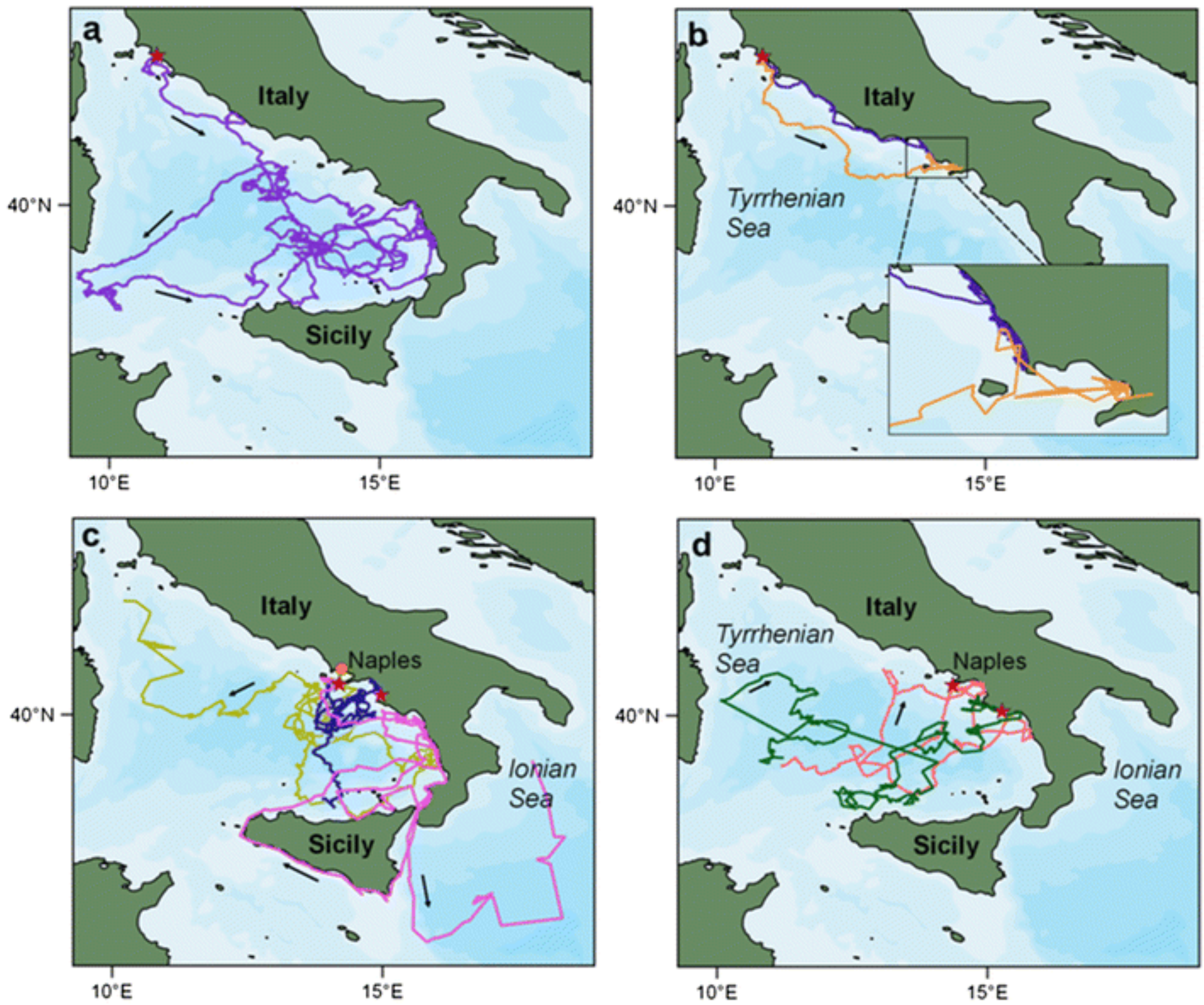

Bathymetry

$\begin{array}{llll}0 & 2000 & 6000 & 10000 \mathrm{~m}\end{array}$

Fig. 1 


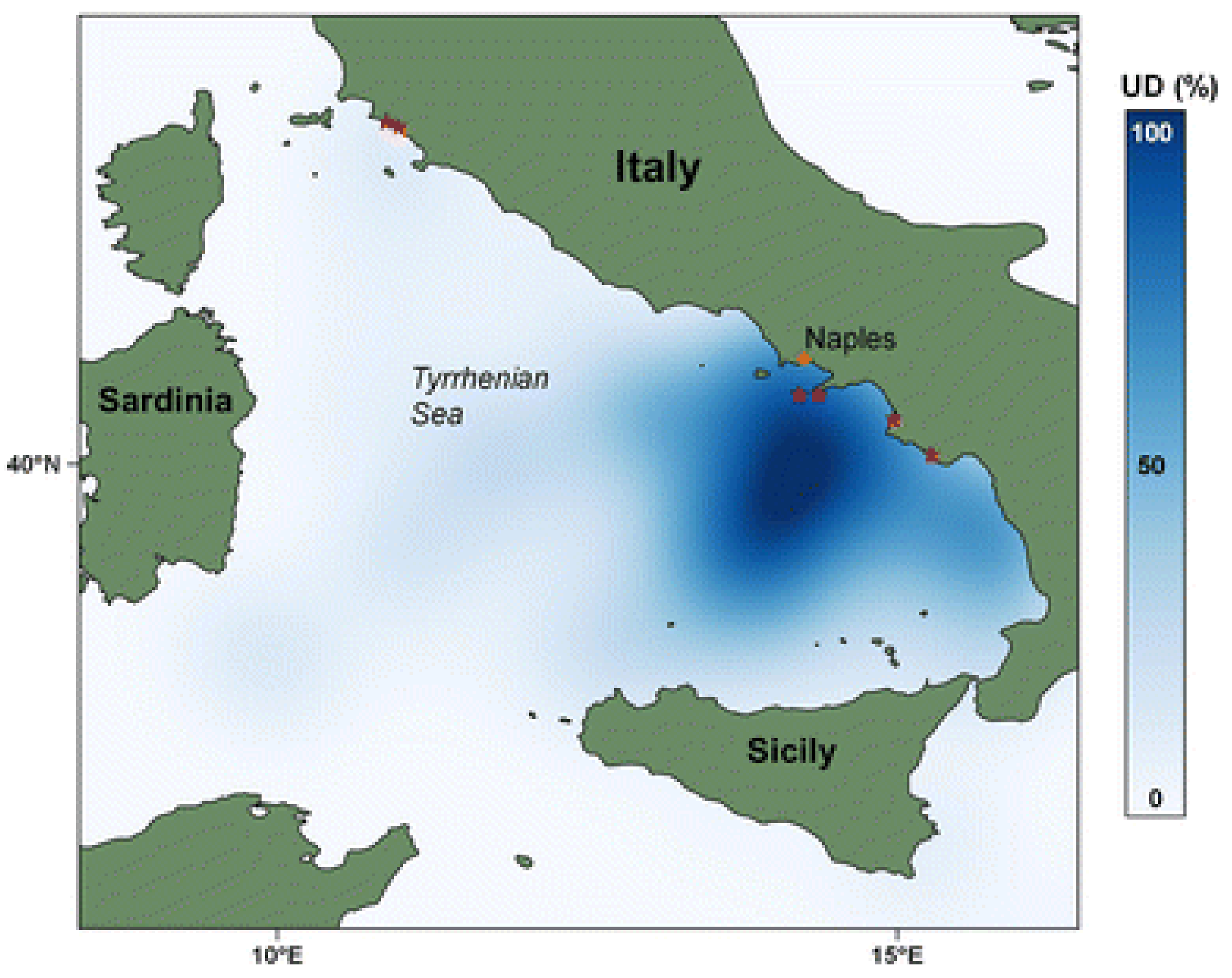

Fig. 2 


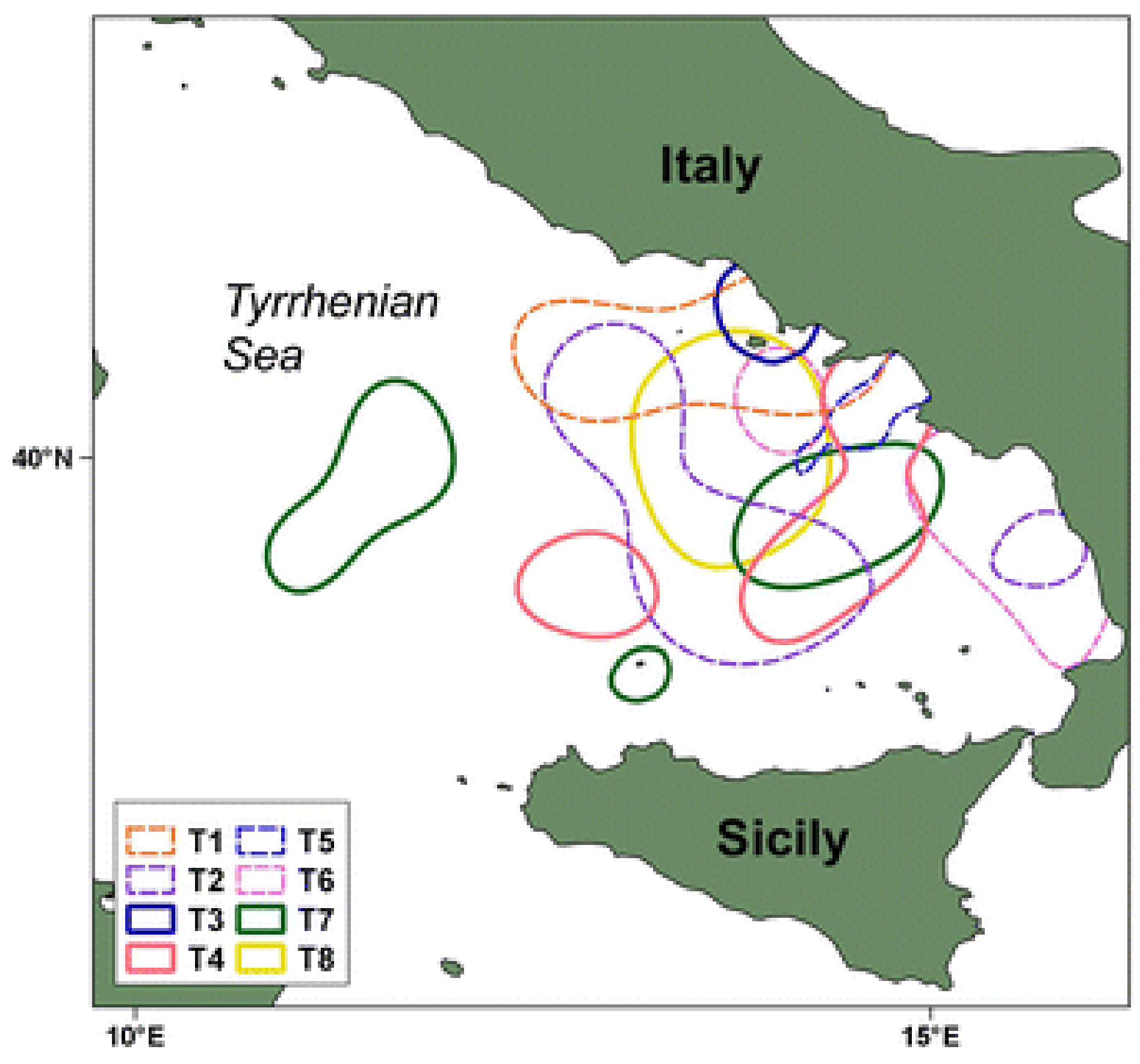

Fig. 3 